Proc. Estonian Acad. Sci. Biol. Ecol., 2005, 54, 1, 67-80

\title{
Fish kill in Lake Peipsi in summer 2002 as a synergistic effect of a cyanobacterial bloom, high temperature, and low water level
}

\author{
Külli Kangur*, Andu Kangur, Peeter Kangur, and Reet Laugaste \\ Võrtsjärv Limnological Station, Institute of Zoology and Botany, Estonian Agricultural University, \\ 61101 Rannu, Tartumaa, Estonia
}

Received 5 July 2004, in revised form 3 January 2005

\begin{abstract}
In Lake Peipsi $\left(3550 \mathrm{~km}^{2}\right.$, mean depth $\left.7.1 \mathrm{~m}\right)$ sporadic fish kills have been registered repeatedly since 1959 during cyanobacterial blooms in warm summers. At the time of the excessive fish kill in August 2002 comprehensive investigations of phytoplankton abundance, key physical and chemical parameters of lake water (including diurnal fluctuations of the dissolved oxygen and ammonium ion concentrations and $\mathrm{pH}$ ) as well as species composition and number of dead fish were carried out along the Estonian shore. The aim of the study was to assess how many fish were killed and to determine ecological conditions in the lake that led to the fish kill. The results suggest that the fish kill was induced by the synergistic effect of several unfavourable conditions, which appeared in the lake during the strong bloom of the cyanobacterium Gloeotrichia echinulata accompanied with continuous hot weather and decreasing water level. A combination of factors such as high water temperature (up to $\left.26^{\circ} \mathrm{C}\right)$, low water level $(70 \mathrm{~cm}$ below the long-term average), great spatial and diurnal variations in the dissolved oxygen (saturation 25-165\%) and ammonium ion (up to $0.33 \mathrm{mg} \mathrm{N} \mathrm{L}^{-1}$ ) concentrations as well as in the $\mathrm{pH}(7.7-9.5)$ were responsible for the mass mortality of fish. The influence of cyanotoxins on the condition of fish cannot be neglected either. Ruffe, a bottom dwelling fish, suffered the most severely.
\end{abstract}

Key words: bloom of cyanobacteria, fish kill, water level, Lake Peipsi.

\section{INTRODUCTION}

A fish kill is a sudden death of a large number of aquatic animals including fish (Fish kill, 2004). Fish kills in natural waters can indicate poor water quality

\footnotetext{
* Corresponding author, kkangur@zbi.ee
} 
and environmental health (Klemm et al., 1993). Fish die as a result of a wide variety of natural and man-induced causes. Natural fish kills are caused by phenomena such as acute temperature change; decomposition of natural organic materials; appearance of toxic algae; parasitic, bacterial and viral epidemics; and other reasons (e.g., Klemm et al., 1993; Helfrish \& Smith, 2000). Man-induced fish kills may be attributed to water pollution. Most fish kills result from natural events, although people can influence their frequency and severity. Low dissolved oxygen levels are probably the most common cause of fish kills (Fish kill, 2004).

Fish kills sometimes accompany cyanobacterial (blue-green algae) blooms. In L. Peipsi cyanobacterial blooms have been documented since the 19th century (Laugaste et al., 2001). A summer water bloom caused by the blue-green Gloeotrichia echinulata (J. S. Smith) P. Richter was noticed there already in 1895 (Kullus, 1964), later mass development of the cyanobacteria Aphanizomenon flosaquae (L.), Anabaena spp., and Microcystis spp. was observed as well (VinkelVoore, 1935; Laugaste et al., 2001). These cyanobacteria are potentially cyanotoxins producing species (e.g., Toxic cyanobacteria, 1999; Carmichael, 2001; Wolfstein, 2003). In recent years strong and long lasting (up to November) algal blooms were repeatedly observed in the lake (Kangur et al., 2002a, 2003a). Since the 1990s the biomass of phytoplankton has increased due to a large shift towards cyanobacteria, and an intensive water bloom occurred in the hot and dry summer of 2002 (Kangur et al., 2002b, 2003a).

It is generally recognized that cyanobacterial blooms are the direct consequence of the lake eutrophication. However, Reynolds \& Petersen (2000) found that the appearance of a cyanobacterial bloom is usually caused by hydrophysical and weather conditions. Once physical requirements of algae are satisfied, the question of chemical resources will arise. This is in accordance with our observations on L. Peipsi, where the time and duration of algal blooms were found to depend mainly on weather conditions (Kangur et al., 2003b).

Sporadic fish kills occurred in the lake during calm warm periods and strong cyanobacterial blooms in summer. A fish kill during the bloom of Aphanizomenon was first described in L. Pihkva (Pskov) in summer 1959 (Semenova, 1960), another, a massive smelt (Osmerus eperlanus (L.)) kill, hit the whole lake in 1972 (Kuderskij \& Fedorova, 1977). Nevertheless, the ecological conditions in the lake that led to the sudden large-scale fish mortality have not been analysed in detail so far. Comparatively few studies deal with fish habitat parameters exactly during a fish kill.

During the first half of August 2002 a mass fish kill occurred in L. Peipsi. However, hikers had reported seeing dead fish already at the end of July along the shoreline of the northern part of the lake. We operatively started comprehensive investigations on the lake aiming at clarifying the reasons for the unexpected ecologically critical situation in the lake that was lethal to fish. The present paper 
summarizes the results of these investigations and points to factors that determine the likelihood of a summer fish kill in L. Peipsi, the major inland fishery waterbody in Estonia.

\section{STUDY AREA}

Lake Peipsi, the largest transboundary lake in Europe, is located on the border of Estonia and Russia. The total area of the lake is $3555 \mathrm{~km}^{2}$, its mean depth is $7.1 \mathrm{~m}$ and maximum depth is $15.3 \mathrm{~m}$ (Jaani, 2001). The lake consists of three unequal parts: the largest and deepest northern L. Peipsi s.s. $\left(2611 \mathrm{~km}^{2}\right.$, mean depth $8.3 \mathrm{~m}$, maximum depth $12.9 \mathrm{~m})$, the southern L. Pihkva (Pskov) $\left(708 \mathrm{~km}^{2}\right.$, $3.8 \mathrm{~m}, 5.3 \mathrm{~m})$, and the narrow strait-like L. Lämmijärv $\left(236 \mathrm{~km}^{2}, 2.5 \mathrm{~m}, 15.3 \mathrm{~m}\right)$ connecting them (Fig. 1). The lake lies at $30 \mathrm{~m}$ above sea level. The volume of the whole lake is $25 \mathrm{~km}^{3}$, and the residence time of water is about two years. The catchment area of L. Peipsi is $47800 \mathrm{~km}^{2}$. There are about 240 inlets into the lake. The main inflows are the Velikaya River in the south and the Emajõgi River in the west. The only outflow is through the Narva River into the Gulf of Finland. The water level is not regulated, while fluctuations are large, $3.04 \mathrm{~m}$ for the last 80 years (Jaani, 1996). The average annual range of water level fluctuations is $1.15 \mathrm{~m}$. The lake is well mixed by the waves and currents. The ice cover lasts usually from December to April. Lake water is the warmest (usually $21-22^{\circ} \mathrm{C}$ in open water) in July-August. The mean water $\mathrm{pH}$ (for the whole lake) was 8.4 (95\% tolerance limits 7.7-9.1) in 1992-2001 (Kangur et al., 2003b). Water transparency by Secchi disc was mostly $0.9-3.3 \mathrm{~m}$ with an overall mean of $1.7 \mathrm{~m}$. In 1992-2001 the overall mean alkalinity was $2.43 \mathrm{mmol} \mathrm{L}^{-1}$, total phosphorus $\left(\mathrm{P}_{\text {tot }}\right)$ content $46 \mathrm{mg} \mathrm{P} \mathrm{m}^{-3}$, and total nitrogen content $698 \mathrm{mg} \mathrm{N} \mathrm{m}^{-3}$. The trophic level of the three parts of the lake is different and increases from north to south, e.g. mean $P_{\text {tot }}$ in the years 1992-2001 was $41 \mathrm{mg} \mathrm{P} \mathrm{m}^{-3}$ in L. Peipsi s.s., $56 \mathrm{mg} \mathrm{P} \mathrm{m}^{-3}$ in L. Lämmijärv, and $72 \mathrm{mg} \mathrm{P} \mathrm{m}^{-3}$ in L. Pihkva (Kangur et al., 2003b). Lake Peipsi supports a significant fishery, producing $85-88 \%$ of the total freshwater catch of fish in Estonia (Vetemaa et al., 1999). According to the commercial statistics, the average annual total catch of fish was 7200 tonnes $(20 \mathrm{~kg} / \mathrm{ha})$ in 1998-2002. The lake is an excellent recreational waterbody. However, the most valuable characteristic of this lake is its large amount of relatively clean fresh water.

\section{MATERIALS AND METHODS}

On 6, 9, and 14 August 2002 the western shoreline of L. Peipsi s.s. was surveyed from Varnja in the south to Alajõe in the north. We analysed the species 
composition of dead fish, counted and measured them at 10 sites (altogether 36 fish samples on the shoreline sections with a length of $1 \mathrm{~m}$ each) along the Estonian shore to assess the numbers of dead fishes and the influence of the fish kill on the stock. The approximate weight of the dead ruffe was recalculated according to the length-weight relationship of ruffe in L. Peipsi (Kangur et al., 2003c). Key physical and chemical variables (water transparency, temperature, $\mathrm{pH}$, dissolved oxygen and ammonium ion content of water) were measured at 10 stations along the shore (Fig. 1). Diurnal observations of hydrochemistry were carried out on 15/16 August 2002 at the Kodavere and Varnja stations (Fig. 1).

Water transparency was measured with a Secchi disc. Temperature and $\mathrm{pH}$ were measured at the time of sampling. The chemical composition of water

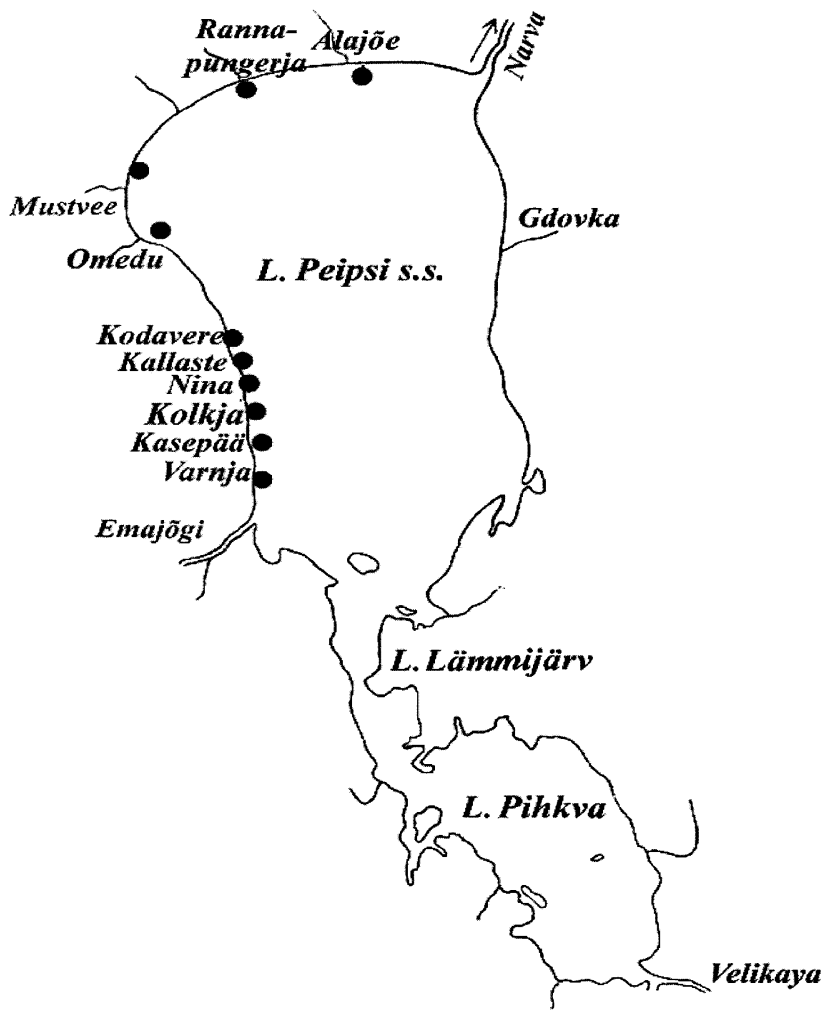

Fig. 1. Location of sampling stations on L. Peipsi in August 2002. 
(oxygen and ammonium ion $\left(\mathrm{NH}_{4}{ }^{+}\right.$) content) was analysed by Tartu Environmental Researchers Ltd. The methods of chemical analysis have been published previously (Starast et al., 2001). The data on the water level and temperatures were obtained from the Estonian Meteorological and Hydrological Institute.

Filtrations for chlorophyll (Chla) measurements were carried out on the day of sampling. To determine Chla, the plankton sample was concentrated on Whatman glass fibre filters (GF/C). The pigments were extracted with $96 \%$ ethanol and analysed spectrophotometrically (Recommendations, 1979). The equations of Jeffrey \& Humphrey (1975) were applied in the calculations of Chla. Phytoplankton samples were preserved with Lugol's solution. Fixed materials were identified and counted using the Utermöhl (1958) technique. Some samples of water were sent to the Institute for Inland Water Management and Waste Water Treatment (RIZA) in The Netherlands (Wolfstein, 2003) and to the National Institute of Chemical Physics and Biophysics in Tallinn for analysis of cyanotoxins. The results of later analysis are presented in another article in this collection (Tanner et al., 2005).

\section{RESULTS}

\section{Early bloom of cyanobacteria and an abrupt shift in the ecosystem in summer 2002}

Weekly observations on L. Peipsi showed that in summer 2002 the blooming of Gloeotrichia echinulata started at the beginning of June, a month earlier than usual. The abundance of this macroscopic cyanobacterium, together with Anabaena cincinalis Rabenh., increased in July-August with continuous hot weather and decreasing water level (Fig. 2), and the ecological situation in the lake deteriorated quickly. At the beginning of August 2002 the water temperature rose up to $26^{\circ} \mathrm{C}$ (Fig. 2). The Chla content in the water close to the shore reached $400 \mathrm{mg} \mathrm{m}^{-3}$ (Fig. 3) and the phytoplankton biomass $250 \mathrm{~g} \mathrm{~m}^{-3}$ (Fig. 4). In the northern part of the lake both the Chla content and the phytoplankton biomass increased about ten times in five days (Figs. 3 and 4) due to the change in the wind direction. In the open water the phytoplankton biomass (19-27 $\mathrm{g} \mathrm{m}^{-3}$ ) was 4-5 times higher than usual in summer (geometric mean $5.0 \mathrm{~g} \mathrm{~m}^{-3}$ with $95 \%$ tolerance limits of $0.7-37.5 \mathrm{~g} \mathrm{~m}^{-3}$ in 1992-2001; Kangur et al., 2003b). Due to large algal masses the Secchi disc transparency of water near the western shore of the lake at a depth of $0.8-1.0 \mathrm{~m}$ decreased to $0.3-0.4 \mathrm{~m}$. The shore of the lake was in several places covered with a layer of Gloeotrichia globules. Everywhere on the shore blue areas of decomposing cyanobacteria and collections of dead fish were observed. 

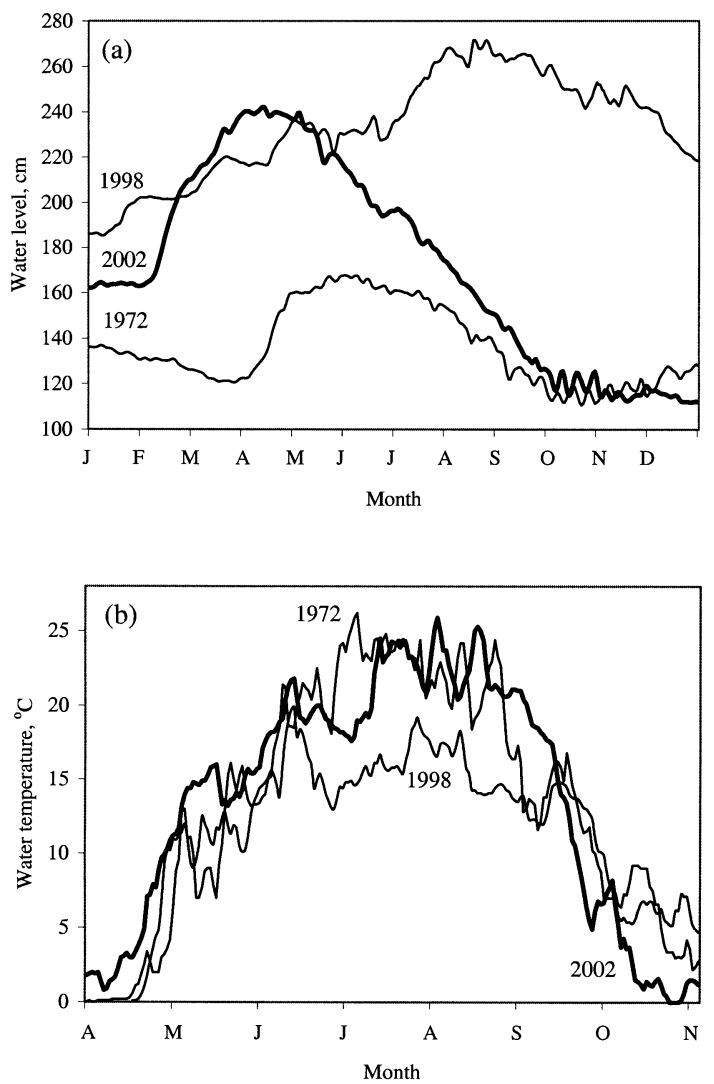

Fig. 2. Seasonal changes of water level (a) and water temperature (b) in the years of fish kill (1972 and 2002) and a wet year (1998).

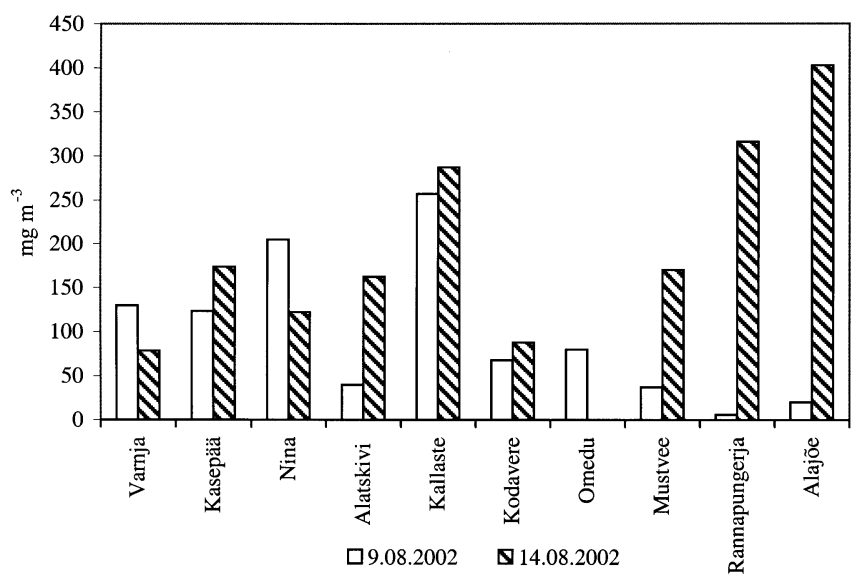

Fig. 3. The chlorophyll $a$ content at sampling stations on L. Peipsi in August 2002; sampling stations from south to north. 


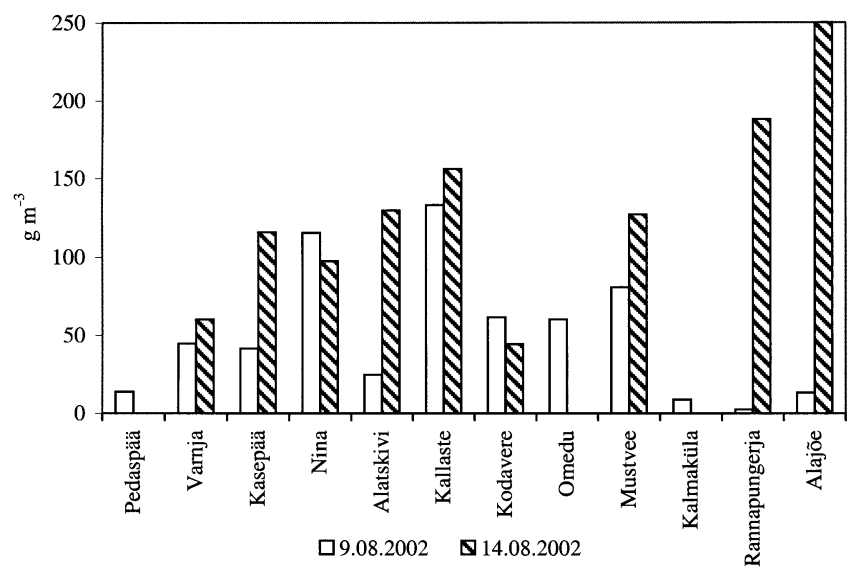

Fig. 4. The biomass of phytoplankton at sampling stations on L. Peipsi in August 2002; sampling stations from south to north.

\section{Numbers and species of fish killed}

Thousands of dead fish, mostly ruffe Gymnocephalus cernuus (L.), but also some other fishes were observed on the shore. The fish kill happened mostly in the open water of the lake, with dead fish accumulating in shallow water and along the shore. Waves placed dead fish into stripes, which extended for kilometres along the shore. As a reflection of the decrease in the water level and changes of the wind direction, dead fish formed multiple stripes on the shore. This means that the fish kill occurred during a longer period.

The heaviest concentration of dead ruffe (460 specimens per $1 \mathrm{~m}$ of shoreline) was along the northern coast of Cape Nina (Fig. 5). Furthermore, on the shore and in the water big dead pikeperch Sander lucioperca (L.), perch Perca fluviatilis L., burbot Lota lota (L.), pike Esox lucius L., bream Abramis brama (L.), and roach Rutilus rutilus (L.) were lying. The number and measurements of these species found north from Kallaste are presented in Table 1.

According to our measurements, in August 2002 the average number of dead ruffe per $1 \mathrm{~m}$ of shoreline reached 135 (range 46-460) specimens with an average standard length of $9 \mathrm{~cm}$ (total weight about $13 \mathrm{~g}$ ). Taking into account data mentioned before, and the length of Estonian shoreline of L. Peipsi s.s. (about $150 \mathrm{~km}$ ), the amount of dead ruffe on the Estonian shore was at least 260 tonnes. Unfortunately, the amount of dead fish in the current Russian territory of L. Peipsi, as well as the fish that remained on the bottom of the lake or that were consumed by scavengers, is unknown.

We observed abnormal behaviour of fish. Ruffe, which usually dwell on the bottom, were slowly moving near the surface. Sometimes it was possible to catch dying fish by hand, sometimes they were able to dive, though. During the diurnal 


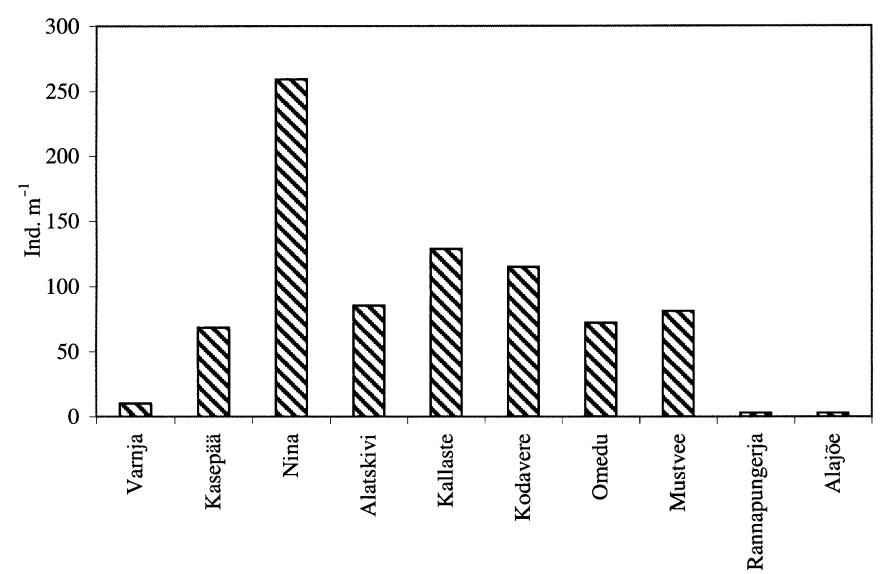

Fig. 5. The number of dead ruffe per $1 \mathrm{~m}$ of the shoreline of L. Peipsi on 9 August 2002.

Table 1. Species composition, number and measurements of dead fish on the shore of L. Peipsi at Kallaste in August 2002

\begin{tabular}{l|c|c|c}
\hline \multirow{2}{*}{$\begin{array}{c}\text { Fish } \\
\text { species }\end{array}$} & \multicolumn{2}{|c|}{ Length of fish, cm } & \multirow{2}{*}{$\begin{array}{c}\text { Number of fish } \\
\text { per } 80 \text { m of lake shore }\end{array}$} \\
\cline { 2 - 3 } Pikeperch & 25 & Range & 70 \\
Perch & 22 & $16-40$ & 50 \\
Roach & 25 & $14-27$ & 3 \\
Pike & 36 & $23-27$ & 2 \\
Burbot & 37 & $37-35$ & 2
\end{tabular}

observations, in the evening we noticed on the surface water shoals of fish fry (mainly roach of 3-4 cm length), which were still capable of diving in the case of disturbance, but in the morning most of them were already dead. At sunrise a large amount of fish fry lay between plants. This means that a mass fish kill had occurred at night or during the early morning hours.

\section{Diurnal variation in the oxygen and ammonium ion content and in the $\mathrm{pH}$}

Measurements at 10 stations along the shore and diurnal observations at two stations showed great spatial and temporal variations in the oxygen (saturation 25-165\%) and ammonium ion (up to $0.33 \mathrm{mg} \mathrm{N} \mathrm{L}^{-1}$ ) content as well as in the $\mathrm{pH}$ 
(7.7-9.5). Supersaturation of water with dissolved oxygen during the day and the following depletion of oxygen to a level lethal to fish was observed during the night (Fig. 6). The lowest content of dissolved oxygen in the open water $\left(2 \mathrm{mg} \mathrm{O}_{2} \mathrm{~L}^{-1}\right)$ was measured just before sunrise. The same pattern of diurnal changes was found in the case of the pH (Fig. 6), which reached the highest values of 9.5 at daylight. The ammonium ion content was the highest (up to $0.33 \mathrm{mg} \mathrm{N} \mathrm{L}^{-1}$ ) in the morning hours (Fig. 7). This exceeds the long-term average value for the growing season $\left(0.024 \mathrm{mg} \mathrm{NH}_{4}{ }^{+} \mathrm{L}^{-1}\right.$ with $95 \%$ tolerance limits $0.002-0.25 \mathrm{mg} \mathrm{L}^{-1}$ in 1992-2001) about 14 times.

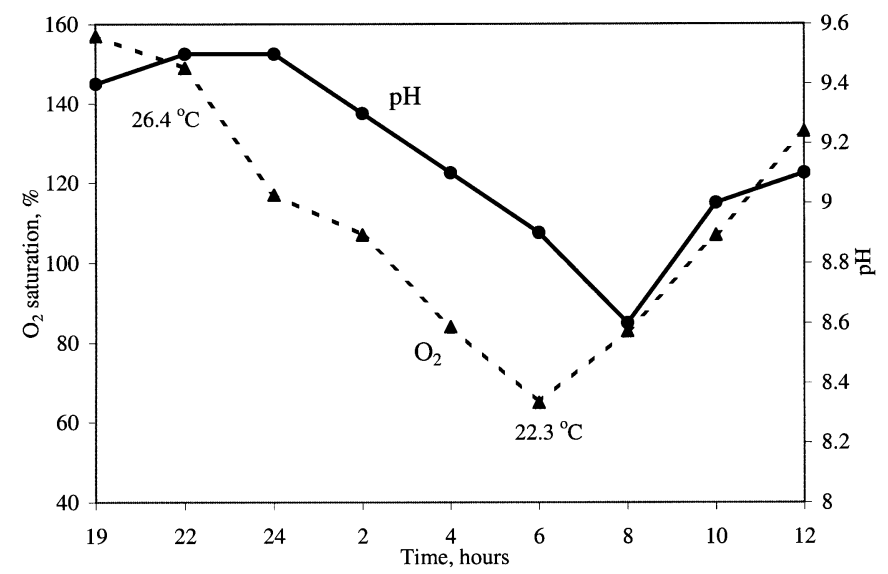

Fig. 6. Diurnal changes of water temperature, oxygen saturation, and $\mathrm{pH}$ in the littoral zone of L. Peipsi on 15/16 August 2002.

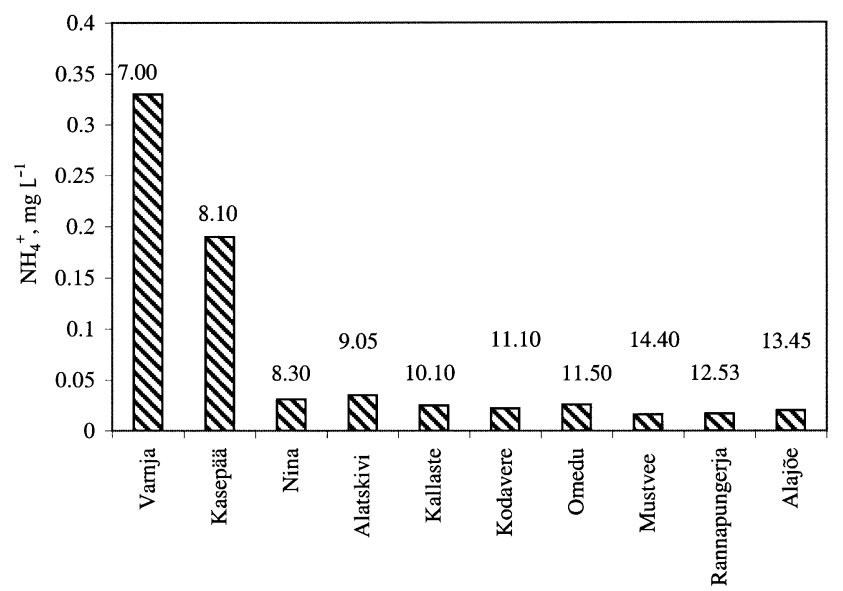

Fig. 7. The content of ammonium ion in the littoral zone of L. Peipsi on 9 August 2002. Sampling stations from south to north; sampling time is indicated above the columns. 


\section{DISCUSSION}

Our data indicate that the fish kill of 2002 in L. Peipsi resulted from natural events and was induced by the synergistic effect of several unfavourable environmental conditions for fish. As in many other waterbodies the extensive fish kill in L. Peipsi occurred in the hottest days of midsummer and was associated with a strong cyanobacterial bloom, which led to oxygen deficiency in the water at night. However, several contributory factors (e.g., high water temperature and low water level) that occurred simultaneously also deteriorated the fish habitat.

Blooms of G. echinulata are common in L. Peipsi in July and August (Laugaste et al., 2001). However, in 2002 its mass development started extremely early in spring. Already on the first days of June numerous spherical colonies (with diameters of several millimetres) of this alga were observed in the water. Gloeotrichia echinulata often forms blooms in moderately eutrophic lakes in summer (KarlssonElfgren et al., 2004). In L. Peipsi it was abundant in the moderately eutrophic northern part of the lake and rare in the strongly eutrophic southern part of the lake (Laugaste \& Lessok, 2004). In 2002 the water bloom expanded during JulyAugust along with the continuous hot and calm weather and decreasing water level (Fig. 2). The location of alga masses depended on the wind direction and changed drastically within a few days. Therefore also dead fish appeared in the lake.

Excess of phytoplankton biomass may itself harm the fish. Moreover, in L. Peipsi algae became so densely concentrated that they generated oxygen supersaturation due to intensive photosynthesis during daylight and depletion at night (Fig. 6). Algae consume oxygen at night for respiration, and the decomposition of dead algae may also lead to oxygen depletion to a level lethal to fish.

Our results suggest that the excessive fish kill in L. Peipsi in summer 2002 was mainly caused by the low dissolved oxygen content in the water during night accompanied with high temperature as well as high $\mathrm{pH}$ and ammonium ion content. Warm water is less capable of holding oxygen gas in solution than cool water. This physical phenomenon puts the fish in double jeopardy because at high water temperatures their metabolic rates increase, hence their physiologic demand for oxygen increases (Francis-Floyd, 2003). According to Müller \& Stadelmann (2004), fish, such as coregonids, require at least $4 \mathrm{mg} \mathrm{O}_{2} \mathrm{~L}^{-1}$ to survive in the long term. Most species of fish are distressed when the oxygen content falls to 2$4 \mathrm{mg} \mathrm{L}^{-1}$; mortality usually occurs at concentrations less than $2 \mathrm{mg} \mathrm{L}^{-1}$ (FrancisFloyd, 2003). In L. Peipsi we measured the oxygen content of $2 \mathrm{mg} \mathrm{O}_{2} \mathrm{~L}^{-1}$ in the open water in the early morning, while the bottom layers of water were even more oxygen-deficient. An evidence for oxygen deficiency in L. Peipsi was the abnormal behaviour of fish. Bottom dwelling fish such as ruffe were ascending from the bottom to the surface water gulping for air. Our diurnal observations also showed that most of the fish died during the night (before sunrise) when the dissolved oxygen content of the water was the lowest. 
The ability to tolerate low dissolved oxygen levels depends on the species of fish (Francis-Floyd, 2003). Smelt and ruffe as the relatively oxygen-demanding fishes have suffered the most in L. Peipsi. In the summers of 1959 and 1972, mass kills of smelt caused by severe night-time water anoxia were observed in the lake (Pihu \& Kangur, 2000), while ruffe suffered most seriously in summer 2002. In 1972-1974 smelt was not caught at all, but a quick recovery of its stock followed in 2-3 years. A quick recovery of the stock is possible in the case of fishes with a short life cycle and fast reproduction. Being a species with high fecundity and low length of maturity, ruffe can quickly restore its stock after disastrous events. Therefore, the extensive kill of ruffe in summer 2002 has probably no long-term effect on the stock of this fish in L. Peipsi.

We saw many fish-consuming animals and birds (e.g. foxes and crows) on the shore of the lake searching for food. This means that only a fraction of the dead fish was ever observed as many of them were decomposed on the lake bottom or eaten by scavengers.

The water bloom in L. Peipsi was accompanied by sudden changes in the water $\mathrm{pH}$ and ammonium ion content (Figs. 6 and 7), which might be dangerous for fish. Due to the intensive photosynthesis, the water $\mathrm{pH}$ rose up to 9.5. An elevated concentration of ammonium ion, released in the course of the decomposition of dead algae, was measured in the morning hours. At $\mathrm{pH}>9$ most ammonium is converted to toxic ammonia $\left(\mathrm{NH}_{3}\right)$, which can kill fish (Randall \& Wicks, 2000). According to Randall \& Wicks (2000), many fishes have difficulty excreting ammonia when exposed to alkaline conditions. Water of $\mathrm{pH}$ above 9.5 can be toxic, even though it contains little or no ammonia, because ammonia levels rise to toxic levels in the fish as a result of impaired excretion (Randall \& Wicks, 2000). Large-scale diurnal fluctuations of the $\mathrm{pH}$ and ammonium ion content together with a high water temperature can cause a fish kill or at least weaken the fish and make them more susceptible to other stresses.

The influence of cyanobacterial toxins on the condition of fish cannot be neglected, either. Cyanobacteria can produce a wide range of toxins, including microcystins, whose elevated concentrations were measured in L. Peipsi (Wolfstein, 2003; Tanner et al., 2005). According to Wolfstein (2003), it cannot be excluded that cyanotoxins played a role in the fish kill in L. Peipsi. Maybe the concentration of microcystins was not lethal, but it affected the condition of the fish, which were then more vulnerable to the unfavourable environmental conditions (Wolfstein, 2003). For several fish species microcystins may be toxic after being eaten (Lirås et al., 1998; Kamjunke et al., 2002). Besides acute toxicity, e.g. damage to liver, kidney, or gills, there are several sublethal and indirect effects that may harm the fish. However, the long-term coexistence of lacustrine animals and cyanobacteria might have given the animals living in the water an opportunity to develop a mechanism making them more resistant to the toxin (Lirås et al., 1998).

Along with the strong water bloom, high water temperature and progressive water level reduction during the summer were the most important factors contributing to the deterioration of the fish habitat in L. Peipsi in summer 2002. 
An analogous situation was observed in the lake in summer 1972 (Fig. 2), when an excessive smelt kill occurred in the whole waterbody. In both years the water level dropped during summer down to $70 \mathrm{~cm}$ below the long-term average and the volume of water in the lake decreased by a tenth, which increased concentrations of nutrients and amplified eutrophication phenomena (Kangur et al., 2003a). The ecological situation in the lake correlated strongly with the lake's natural water level fluctuations. Accelerated eutrophication periods of L. Peipsi appeared in dry years with low water level despite the reduced external load (Kangur et al., 2003a).

Overall, our data indicate that the excessive fish kill in L. Peipsi in summer 2002 was induced by a massive cyanobacterial bloom accompanied with oxygen depletion in water during night and the synergistic effect of several contributing factors, e.g. high water temperature, low water level, and great diurnal variations in the ammonium ion content as well as in the $\mathrm{pH}$. The likelihood of the appearance of ecologically critical situations in a lake depends mainly on weather conditions and water level, both uncontrollable by humans. Therefore in shallow L. Peipsi, extensive fish kills are likely to occur again in the summers when high temperature is accompanied by a low water level. Moreover, the eutrophication of L. Peipsi (the addition of nutrients to the lake) will raise the intensity of blooms. Eutrophication and the increase in temperature are acting in the same direction: both are increasing the probability of fish kills.

\section{ACKNOWLEDGEMENTS}

This work was supported by the Estonian target financed project No. 0362483s03 and grant No. 4986 of the Estonian Science Foundation. In this study data of the Estonian state monitoring programme were used.

\section{REFERENCES}

Carmichael, W. W. 2001. The cyanotoxins - bioactive metabolites of cyanobacteria: occurrence, ecological role, taxonomic concerns and effects on humans. J. Phycol., 37(3), 9-10.

Fish kill investigation manual. 2004. Northern Territory Government. Department of Business, Industry \& Resource Development. Fish. Rep., 70, 1-15.

Francis-Floyd, R. 2003. Dissolved Oxygen for Fish Production. http://edis.ifas.ufl.edu/BODY_FA002

Helfrish, L. A. \& Smith, S. A. 2000. Fish Kills: Their Causes and Prevention. Virginia Cooperative Extension. Publ. 420-252. http://www.ext.vt.edu/pubs/fisheries/420-252/420-252.html

Jaani, A. 1996. Hydrology and water balance of Lake Peipsi. Hydrobiologia, 338, 11-23.

Jaani, A. 2001. The location, size and general characterization of Lake Peipsi and its catchment area. In Lake Peipsi. II Meteorology, Hydrology, Hydrochemistry (Nõges, T., ed.), pp. 10-17. Sulemees Publishers, Tartu.

Jeffrey, S. W. \& Humphrey, G. F. 1975. New spectrophotometric equations for determining chlorophylls $a, b, c_{1}$ and $c_{2}$ in higher plants, algae and natural phytoplankton. Biochem. Physiol. Pflanzen, 167, 191-194. 
Kamjunke, N., Schmidt, K., Pflugmacher, S. \& Mehner, T. 2002. Consumption of cyanobacteria by roach (Rutilus rutilus): useful or harmful to the fish? Freshwater Biol., 47, 243-250.

Kangur, K., Möls, T., Haberman, J., Kangro, K., Laugaste, R., Milius, A., Nõges, T., Timm, H., Timm, T. \& Zingel, P. 2002a. Peipsi järve ökoloogilise seisundi muutused 1992-2001. In Eesti keskkonnaseire 2001, pp. 57-64. Tartu Ülikool.

Kangur, K., Milius, A., Möls, T., Laugaste, R. \& Haberman, J. 2002b. Lake Peipsi: changes in nutrient elements and plankton communities in the last decade. J. Aquat. Ecosystem Health Manage., 5, 363-377.

Kangur, K., Möls, T., Haldna, M., Kangur, A., Kangur, P., Laugaste, R., Milius, A. \& Tanner, R. 2003a. Peipsi elustiku, biogeenide ja veetaseme ühisdünaamika ning kriitiliste olukordade risk. In Kaasaegse ökoloogia probleemid (Frey, T., ed.), pp. 73-83. Tartu.

Kangur, K., Möls, T., Milius, A. \& Laugaste, R. 2003b. Phytoplankton response to changed nutrient level in Lake Peipsi (Estonia) in 1992-2001. Hydrobiologia, 506-509, 265-272.

Kangur, P., Kangur, A., Kangur, K. \& Möls, T. 2003c. Condition and growth of ruffe Gymnocephalus cernuus (L.) in two large shallow lakes with different fish fauna and food resource. Hydrobiologia, 506-509, 435-441.

Karlsson-Elfgren, I., Rengefors, K. \& Gustafsson, S. 2004. Factors regulating recruitment from the sediment to the water column in the bloom-forming cyanobacterium Gloeotrichia echinulata. Freshwater Biol., 49, 265-273.

Klemm, D. J., Stober, Q. J. \& Lazorchak, J. M. 1993. Fish field and laboratory methods for evaluating the biological integrity of surface waters. EPA/600/R-92/111. U.S. Environmental Protection Agency, Cincinnati, Ohio.

Kuderskij, L. A. \& Fedorova, G. V. 1977. Decrease of smelt stocks in large waterbodies in the northwestern region of the European part of the USSR in 1973-1975. Rybokhozyajstvennoe izuchenie vnutrennikh vodoemov, 20, 3-8 (in Russian).

Kullus, L. 1964. Peipsi-Pihkva järve uurimisest ajavahemkul 1850-1917. In Eesti Geograafia Seltsi aastaraamat 1963, pp. 148-158. Tartu.

Laugaste, R. \& Lessok, K. 2004. Planktonic algae and epiphyton of the littoral in Lake Peipsi, Estonia. Limnologica, 34, 90-97.

Laugaste, R., Nõges, T., Nõges, P., Yastremskij, V. V., Milius, A. \& Ott, I. 2001. Algae. In Lake Peipsi. Flora and Fauna (Pihu, E. \& Haberman, J., eds.), pp. 31-49. Sulemees Publishers, Tartu.

Lirås, V., Lindberg, M., Nyström, P., Annadotter, H., Lawton, L. A. \& Graf, B. 1998. Can ingested cyanobacteria be harmful to the signal crayfish (Pacifastacus leniusculus)? Freshwater Biol., 39, 233-242.

Müller, R. \& Stadelmann, P. 2004. Fish habitat requirements as the basis for rehabilitation of eutrophic lakes by oxygenation. Fish. Manage. Ecol., 11, 251-260.

Pihu, E. \& Kangur, A. 2000. Main changes in the ichthyocoenosis of Lake Peipsi since the 1950s. Proc. Estonian Acad. Sci. Biol. Ecol., 1, 81-90.

Randall, D. J. \& Wicks, B. J. 2000. Fishes: ammonia production, excretion and toxicity. Fish physiology, toxicology, and water quality. In Proceedings of the Fifth International Symposium, Hong Kong, November 10-13, 1998 (Thurston, R. V., ed.), pp. 41-50. Ecosystem Research Division, Athens, Georgia.

Recommendations for marine biological studies in the Baltic Sea. 1979. Phytoplankton and chlorophyll. BMB Publ., 5.

Reynolds, C. S. \& Petersen, A. C. 2000. The distribution of planktonic cyanobacteria in Irish lakes in relation to their trophic states. Hydrobiologia, 424, 91-99.

Semenova, N. I. 1960. The reasons of smelt kill in L. Pskov in August 1959. Nauchno-tekhnicheskij byulleten GosNIORKH, 10, 23-24 (in Russian).

Starast, H., Milius, A., Möls, T. \& Lindpere, A. 2001. Hydrochemistry of Lake Peipsi. In Lake Peipsi. II Meteorology, Hydrology, Hydrochemistry (Nõges, T., ed.), pp. 97-131. Sulemees Publishers, Tartu. 
Tanner, R., Kangur, K., Meriluoto, J. \& Spoof, L. 2005. Hepatotoxic cyanobacterial peptides in Estonian freshwater bodies and inshore marine water. Proc. Estonian Acad. Sci. Biol. Ecol., 54, 40-52.

Toxic cyanobacteria in water: a guide to their health consequences, monitoring and management. 1999. WHO (The World Health Organization). http://www.who.int/docstore/water_sanitation_health/ toxicyanobact/ch03.html

Utermöhl, H. 1958. Zur Vervollkommung der quantitatieven Phytoplankton-Methodik. Mitt. Int. Ver. Limnol., 9, 1-38.

Vetemaa, M., Järvalt, A. \& Vaino, V. 1999. Current status and trends in inland fisheries in Estonia. In BAFICO Seminar on Inland Fisheries, pp. 19-28. Tallinn.

Vinkel-Voore, R. 1935. Vee õitsemine Peipsi järvel. Eesti Loodus, 1, 24.

Wolfstein, K. 2003. Microcystins in Lake Peipsi, Estonia. RIZA-WSE, The Netherlands. Project report.

\title{
Kalade massiline suremine Peipsis 2002. a suvel sinivetikate vohamise, kõrge veetemperatuuri ja madala veetaseme ühismõju tulemusena
}

\author{
Külli Kangur, Andu Kangur, Peeter Kangur ja Reet Laugaste
}

Peipsis on sinivetikate vohamise ajal korduvalt täheldatud kalade massilist hukkumist. 1959. ja 1972. a suri hulgaliselt tinti, 2002. a kannatas peamiselt kiisapopulatsioon. 2002. a augustis (kalade suremise ajal) uurisime järve Eestipoolses osas kompleksselt fütoplanktoni ohtrust ja vee füüsikalisi ning keemilisi parameetreid (k.a ammooniumiooni- ja hapnikusisalduse ning pH ööpäevaseid muutusi järvevees) eesmärgiga selgitada ökoloogilisi tingimusi, mis põhjustasid kalade massilist suremist. Hukkunud kalade hulga hindamiseks loendasime ja mõõtsime kaldale uhutud isendeid Varnja ja Alajõe vahelisel kaldalõigul. 2002. a mõjutasid fütoplanktoni arengut erakordselt varane soe kevad ja kuum kuiv suvi. Sinivetika Gloeotrichia echinulata vohamisest põhjustatud veeõitseng algas kuu aega varem kui tavaliselt (juuni algul). Augusti algul ulatus Peipsi kaldalähedases vees fütoplanktoni biomass $250 \mathrm{~g} \mathrm{~m}^{-3}$ ja klorofüll $a$ kontsentratsioon üle $400 \mathrm{mg} \mathrm{m}^{-3}$. Kalade hukkumine oli tingitud veeõitsenguga kaasnenud mitme ebasoodsa teguri koosmõjust, millest olulisemad olid kestvalt kõrge veetemperatuur (üle $26^{\circ} \mathrm{C}$ ), madal veetase ( $70 \mathrm{~cm}$ alla paljuaastase keskmise), sinivetikate vohamisest tingitud ulatuslik ööpäevane vee hapnikusisalduse (25-165\% küllastusest), $\mathrm{pH}(7,7-9,5)$ ja ammooniumiooni sisalduse (kuni $0,33 \mathrm{mg} \mathrm{N} \mathrm{l}^{-1}$ ) kõikumine. Päevavalguses, intensiivse fotosünteesi ajal, oli vesi hapnikuga üleküllastunud, seevastu öösel, kui hapnik kulus vetikamasside hingamiseks ja lagunemiseks, tekkis tugev hapnikupuudus. Intensiivse fotosünteesi puhul tõusis vee $\mathrm{pH}$ üle 9,5. Aluselises vees ( $\mathrm{pH}$ üle 9) läheb ammooniumioon kergesti üle ammoniaagiks, mis on kaladele väga mürgine. Ei saa eitada ka vetikamürkide võimalikku mõju kalade seisundile. 